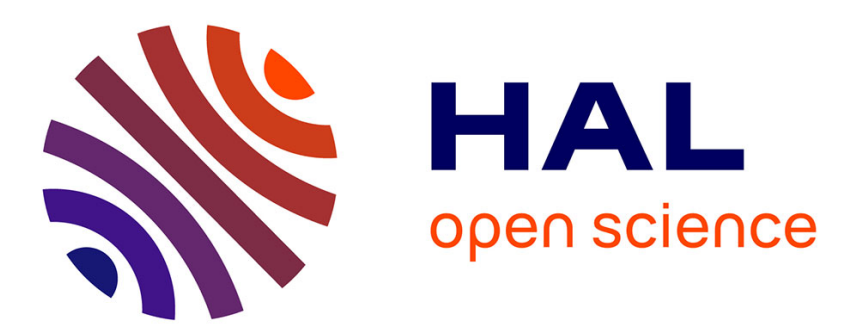

\title{
Mixing of Aleppo pine and Holm oak litter increases biochemical diversity and alleviates $\mathrm{N}$ limitations of microbial activity
}

René Guénon, Thomas A. Day, Sergio Velazco-Ayuso, Raphaël Gros

\section{To cite this version:}

René Guénon, Thomas A. Day, Sergio Velazco-Ayuso, Raphaël Gros. Mixing of Aleppo pine and Holm oak litter increases biochemical diversity and alleviates $\mathrm{N}$ limitations of microbial activity. Soil Biology and Biochemistry, 2017, 105, pp.216-226. 10.1016/j.soilbio.2016.11.023 . hal-01523667

HAL Id: hal-01523667

https://institut-agro-rennes-angers.hal.science/hal-01523667

Submitted on 16 May 2018

HAL is a multi-disciplinary open access archive for the deposit and dissemination of scientific research documents, whether they are published or not. The documents may come from teaching and research institutions in France or abroad, or from public or private research centers.
L'archive ouverte pluridisciplinaire HAL, est destinée au dépôt et à la diffusion de documents scientifiques de niveau recherche, publiés ou non, émanant des établissements d'enseignement et de recherche français ou étrangers, des laboratoires publics ou privés. 


\title{
Mixing of Aleppo pine and Holm oak litter increases biochemical diversity and alleviates $\mathrm{N}$ limitations of microbial activity
}

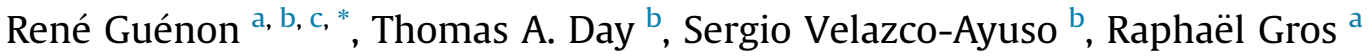 \\ a Institut Méditerranéen de Biodiversité et d'Ecologie marine et continentale, UMR 7263, Aix-Marseille Université, CNRS, IRD, Univ. Avignon, Faculté des Sciences et techniques \\ de Saint-Jérôme, F-13397 Marseille cedex 20, France \\ b School of Life Sciences, Arizona State University, Tempe, AZ 85287, USA \\ ${ }^{\mathrm{c}}$ Brittany Loire University, UP EPHOR, IRSTV, Agrocampus ouest, 2 rue André Lenôtre, Angers F49042, France
}

\section{A B S T R A C T}

Soil $\mathrm{N}$ availability is a primary limitation for plants and microbes in Mediterranean ecosystems. Few studies have examined the role of secondary compounds (e.g. polyphenols and volatile organic compounds) in mixed litter in Mediterranean ecosystems. Here, we ask whether the natural mixing of Aleppo pine and Holm oak litter decreases the inhibitory effect of secondary compounds and increases microbial activities involved in C cycling. In situ $\mathrm{N}$ fertilisation was used to demonstrate the limiting role of $\mathrm{N}$ to soil microbial activities, particularly in pure pine stands, and we hypothesised that these inhibitory effects would be alleviated in mixed litter. We examined the concentrations, structure and diversity of biochemical compounds in litter from single-species or mixed stands of pine and oak, along with associated microbial activities (i.e. net ammonification and nitrification, cellulase, fluorescein diacetate hydrolase (FDAse) and phenol oxidase activities). We tested the relationships between biochemical compounds and microbial activities with co-inertia analyses. Pine litter clearly shaped the biochemical composition of mixed litter in the organic litter horizon, and this mixed litter was dominated by high molecular weight compounds (total phenols, sesqui- and diterpenes). In contrast, oak litter was domi-nated by small compounds such as monoterpenes and hydro-soluble phenols. Pine litter clearly affected microbial activities (i.e. antagonistic effect) in unfertilised mixed litter. We demonstrated by co-inertia analysis that this antagonistic effect was related to $\mathrm{N}$ availability. Mixed litter had the highest VOC (volatile organic compounds) richness and evenness, along with the highest enzyme activities (i.e. synergistic effect), and $\mathrm{N}$ availability did not constrain microbial activities. However, an apparent nitri-fication limitation suggested greater microbial specialisation and efficiency of $\mathrm{N}$ recovery in mixed litter. Our results highlight how mixing two recalcitrant litters can alleviate $\mathrm{N}$ limitation and could explain transition in Mediterranean forest secondary succession.

Keywords: Antagonism,

Non-additivity effect, N availability Secondary compounds, Synergy

\section{Introduction}

Since the late 19th century, silvicultural and postfire reforestation practices in the Northern Mediterranean Basin have promoted monospecific stands of Aleppo pine (Pinus halepensis Mill.), a common pioneer and highly competitive species (Vilà et al., 2003). The potential ecosystem consequences of the resulting loss in tree

\footnotetext{
* Corresponding author. Brittany Loire University, UP EPHOR, IRSTV, Agrocampus ouest, 2 rue André Lenôtre, Angers F49042, France

E-mail addresses: rene.guenon@agrocampus-ouest.fr (R. Guénon), tadday@asu. edu (T.A. Day), sergio.sva@gmail.com (S. Velazco-Ayuso), raphael.gros@imbe.fr (R. Gros).
}

species richness include a decrease in nutrient cycling (Parrotta, 1999) and a decline in community stability (i.e. resistance and resilience) in response to climatic stresses (Royer-Tardif et al., 2010). Additionally, plant productivity of these monospecific stands can be lower than that of more diverse forest stands. Vilà et al. (2007) reported that Mediterranean mixed forest stands produced $30 \%$ more wood than monospecific stands of Aleppo pine or Holm oak (Quercus ilex L.), the most common evergreen that naturally co-occurs in Aleppo pine forests in the Mediterranean basin of southern France and Spain (Pausas et al., 2004; Sheffer, 2012).

Plant litter decomposition, mediated largely by soil microbes, is a major ecosystem process linking plant productivity to nutrient 
cycling (Hobbie, 1992; Chapman and Koch, 2007). In the context of monospecific versus mixed forest stands, the influence of singlespecies versus mixed (composed of foliage of 2 or more species) litter could have significant consequences on nutrient cycling. Compared to single-species litter, decomposition (i.e. mass loss) rates of mixed litter can be additive (i.e. predictable based on the mass loss dynamics of each species when decomposed alone) or non-additive (differing from that expected based on single-species mass loss dynamics) (Gartner and Cardon, 2004). In the case of the latter non-additive responses, decomposition rates of mixed litter can be enhanced or faster than expected (referred to as a synergistic response) or slower than expected (an antagonistic response) (Gartner and Cardon, 2004). We hypothesised that litter in mixed Aleppo pine- Holm oak stands would have greater microbial activity and decomposition rates, leading to greater nutrient availability that could in turn, explain the greater wood productivity observed in mixed forests (Vilà et al., 2007). Two mechanisms could explain this synergistic response: facilitation among microbial communities (e.g. a 'priming' or 'fertilisation' effect) (Chapman et al., 1988) or resource partitioning among microbial communities, known as the niche complementarity effect (Paquette and Messier, 2011). Because the niche complementarity effect can be more important in less productive, harsher environments (Paquette and Messier, 2011), and has a major effect on litter decomposition and nutrient availability in temperate forests (Vos et al., 2013), we suspected this mechanism might be dominant in our system.

The influence of mixed litter on decomposition rates has been assessed in dozens of studies (e.g. Wardle et al., 2006; Lecerf et al., 2011; Chapman et al., 2013; Chomel et al., 2015) and was recently reviewed by Song et al. (2010). Most experiments have included at least one litter species of high quality (i.e. high $\mathrm{N}$ and/or low concentrations of lignin, polyphenols or tannins) (Chapman and Koch, 2007). Litters of pine and oak are both considered recalcitrant, having low N concentrations (Yuste et al., 2012) and high concentrations of secondary compounds such as polyphenols, tannins or terpenes (Fernandez et al., 2013; Sheffer et al., 2015). These biochemical compounds make them relatively unfavourable for microbes (Fioretto et al., 1998; White, 1988; 1994), and in turn can slow the turnover of organic matter and nutrient cycling (Smolander et al., 2006; Chomel et al., 2014). On the other hand, polyphenols can have a positive influence on litter decomposition since they can serve as a $C$ substrate, particularly for fungi (Castells et al., 2004). The decomposition of polyphenols would involve microbial specialisation such as the ability to produce phenol oxidase (Hättenschwiler and Vitousek, 2000).

Net $\mathrm{N}$ mineralisation, a major soil process controlling $\mathrm{N}$ availability, can be limited in early stages of litter decomposition in an evergreen forest, as a result of polyphenols, possibly because of their toxicity to microbes (Fierer et al., 2001). Aleppo pine is a terpene-storing species and needles typically contain relatively high concentrations of monoterpenes which can inhibit $\mathrm{N}$ mineralisation and nitrification (White, 1994). In contrast, Holm oak does not store terpene but its foliage does contain many other polyphenols that are also recalcitrant to decomposers (Brossa et al., 2009; Sheffer et al., 2015).

Most studies that have addressed litter mixtures have been conducted in boreal, temperate or tropical ecosystems. Several studies have addressed litter decomposition in mixed Mediterranean stands (De Oliveira et al., 2010; De Marco et al., 2011; Bonanomi et al., 2010; Maisto et al., 2011; Aponte et al., 2012; Bonanomi et al., 2014; Santonja et al., 2015; Sheffer et al., 2015) but few of these focused on the microbial functions involved in litter decomposition. While Bonanomi et al. (2010) found that mixed litter decomposed faster than single-species litter, it is unclear how mixtures of litters with high concentrations of secondary compounds might accelerate decomposition (Bonanomi et al., 2010; Chapman et al., 2013; Sheffer et al., 2015). To our knowledge, this study is the first to examine how litter mixing influences microbial functions in a Mediterranean ecosystem and could provide an explanation for how mixed litter alleviates $\mathrm{N}$ limitation in forest secondary succession.

The main objectives of this study were 1) to examine the secondary compounds in litter from single-species or mixed stands of Aleppo pine and Holm oak, 2) to assess the effect of mixing litter on microbial activities and 3) to examine the relationship between microbial and biochemical properties and whether these relationships are affected by $\mathrm{N}$ availability. We expected that mixed litter would have a greater richness and evenness of secondary compounds and that their concentrations would be diluted, thereby reducing their inhibitory effects. Thus, a niche complementary effect would improve microbial activities by increasing nutrient mineralisation and availability. We also used in situ inorganic $\mathrm{N}$ fertilisation to alleviate $\mathrm{N}$ limitations on soil microbial activity. We expected greater $\mathrm{N}$ availability would increase microbial activity in early stage of litter decomposition, particularly in monospecific pine litter.

\section{Material and methods}

\subsection{Study site and experimental design}

The study sites were in southeastern France (Provence Alpes Côte d'Azur region) within $50 \mathrm{~km}$ of Marseille. Climate is Mediterranean with dry, hot summers and wet, temperate winters, with precipitation occurring primarily during 4 months (SeptemberNovember and April). Mean annual temperature and precipitation are $13{ }^{\circ} \mathrm{C}$ and $650 \mathrm{~mm}$, respectively (meteorological data of the PACA region, 2000-2007, MétéoFrance).

Three typical Mediterranean forest types were studied: monospecific stands of Aleppo pine, monospecific stands of Holm oak, and mixed stands, almost at equal dominance between pine and oak cover density (i.e. Pine $52 \% \pm 3 \%$ and Oak $48 \% \pm 3 \%$ ). In each stand type, we chose 3 study sites $\left(10,000 \mathrm{~m}^{2}\right)$. All study sites were similar in terms of age of dominant trees (30-35 years old), canopy density (70-90\%), slope (15-20\%), aspect (NW-W) and soils (Calcaric Cambisol of $50 \mathrm{~cm}$ depth (World Reference Base)).

At each study site, two $16 \mathrm{~m}^{2}$ plots, $15 \mathrm{~m}$ apart, were delineated. One plot ('fertilised') received $450 \mathrm{~kg} \mathrm{~N}^{-1}$, applied as ammonium sulphate $\left(\mathrm{NH}_{4}\right)_{2} \mathrm{SO}_{4}$ (granules $<0.2 \mathrm{~mm}$ diameter) in January 2006. We selected this high level of $\mathrm{N}$ fertilisation to maximise in situ $\mathrm{N}$ effects. The second plot ('non-fertilised') served as a control. Overall, the experiment consisted of 3 stand types, 3 sites within each stand type, and 2 plots (fertilised and non-fertilised) within each site.

Four months after the application of the fertiliser (May 2006), two layers of the soil organic horizon (OL: organic litter and OF-H: organic fermentative and humic) comparable in terms of depth among forest types were sampled. The OL horizon was the upper (0-3 cm depth), less fragmented litter layer (easily identifiable to species) while the OF-H horizon (3-7 cm depth) was fragmented, humified, oxidized organic matter, and not identifiable as to litter species. In each plot (both fertilised and unfertilised), we collected 20 randomly located samples from each layer and these were pooled to obtain a composite sample. No contributions from plant species other than Aleppo pine or Holm oak were found in the upper layer which infers that both litter layers were likely comprised of nearly exclusively these 2 species. Samples were kept at $4{ }^{\circ} \mathrm{C}$ until analyses (within 1 week for microbial analyses). Briefly, litter organic matter concentration (\%) was obtained by loss on ignition in a muffle furnace $\left(16 \mathrm{~h}, 550{ }^{\circ} \mathrm{C}\right)$ of $10 \mathrm{~g}$ subsamples for 
each plot. Total organic carbon (TOC) and total nitrogen (TN) contents were measured using a C/N elemental analyser (Flash EA 1112 series ThermoScientific). Water $\mathrm{pH}$ was assessed with a MilliQ water suspension $(1 / 2.5 \mathrm{w} / \mathrm{v})$ after shaking $1 \mathrm{~h}$. Gravimetric water content of litters was obtained by drying subsamples in an oven $\left(80^{\circ} \mathrm{C}, 24 \mathrm{~h}\right)$. All chemical and microbial assays are expressed on an oven-dry mass (DM) basis. The main physico-chemical properties of these litter layers are shown in Table 1.

\subsection{Litter secondary compounds}

Prior to analysis of phenolic concentrations in litters, samples $(\mathrm{n}=18)$ were freeze dried (lyophilised), ground and sieved (0.5$\mathrm{mm}$ mesh). Water-soluble phenols (i.e. polar monomers and dimers) were extracted according to Barlecher and Graça (2005). Briefly, $200 \mathrm{mg}$ of litter subsample was mixed with $5 \mathrm{ml}$ of water and shaken on an orbital shaker ( $1 \mathrm{~h}, 120$ oscillations $\mathrm{h}^{-1}$ ). Total phenols were extracted from $100 \mathrm{mg}$ subsamples in an acetonewater $(70 / 30 \mathrm{v} / \mathrm{v})$ solution (i.e. hydrosoluble and liposoluble compounds). Extracts were filtered and total phenols were assessed with the Folin-Ciocalteu reagent method (Folin and Denis, 1915). Five hundred $\mu \mathrm{l}$ of extract were added to $400 \mu \mathrm{l}$ of $\mathrm{Na}_{2} \mathrm{CO}_{3}(20 \%)$ and $100 \mu \mathrm{l}$ of Folin-Ciocalteu reagent. The mixture was shaken, incubated $\left(2 \mathrm{~h}, 30^{\circ} \mathrm{C}\right)$ and the optical density (OD) was read at $750 \mathrm{~nm}$ with a spectrophotometer (Thermo Spectronic Genesys 20). A standard curve was developed with a tannic acid solution $\left(100 \mathrm{mg} \mathrm{ml}^{-1}\right)$ and OD was expressed in $\mathrm{mg}$ of equivalent phenol $\mathrm{g}^{-1}$ litter DM.

Volatile organic compounds in litters were extracted by water distillation according to a modified procedure of Dob et al. (2005). Fifty g (equivalent dry weight) of fresh litter from each site was cut into small pieces, sieved through 4-mm mesh, and added to $500 \mathrm{ml}$ of distilled water in a 21 boiling flask. The ball was connected to a cooling system equipped with a collector and boiled for $8 \mathrm{~h}$. The VOCs were vaporised, cooled and the condensate was collected in an adjacent column. Droplets were solubilised in $1.5 \mathrm{ml}$ of pure hexane and dried by adding water-free sodium sulphate $\left(\mathrm{Na}_{2} \mathrm{SO}_{4}\right)$. Samples were kept at $-20^{\circ} \mathrm{C}$, and then $0.5 \mu \mathrm{l}$ of extract was injected into a gas chromatograph (Chrompack CHROM 3 - CP 9001) equipped with a $30 \mathrm{~m}$ glass capillary column (CP-SIL-5CB) and a flame ionisation detector (FID) maintained at $280^{\circ} \mathrm{C}$. Helium was used as the carrier gas at a flow rate of $60 \mathrm{ml} \mathrm{h}^{-1}$ and the injector temperature was $250{ }^{\circ} \mathrm{C}$. After an initial oven temperature of $50{ }^{\circ} \mathrm{C}$ (10 min), temperature was increased at a rate of $3{ }^{\circ} \mathrm{C} \mathrm{min}^{-1}$ for 80 min. Peak retention times were readjusted by adding a known content of pure internal standards (i.e. heptane and hexadecane). Areas under each peak were determined by an automated programme in Maestro software. These areas were summed to obtain total intensity of VOCs in each sample (Table 2) and each peak was computed to represent the relative abundance in the sample (Leff and Fierer, 2008). We injected 36 pure terpene standards (30 monoterpenes or monoterpenoids, 3 sesquiterpenes and 3 diterpenes) under the same conditions. A chromatogram (Fig. S1) was typically composed of two classes of retention times (0-25 and 30-85 min). The first class was mainly attributed to monoterpenes (C10 compounds, 90\% of the monoterpenes and monoterpenoids). The second class included mainly intermediate weight compounds such as sesquiterpenes (C15 compounds) and latter diterpenes compounds (C20 compounds) (Dob et al., 2005; Ormeño et al., 2008; Chomel et al., 2014). Indices of VOC diversity and evenness were calculated as described below (section 2.5).

\subsection{Net ammonification and net nitrification}

Net $\mathrm{N}$ mineralisation was assessed according to Guénon et al. (2013). Briefly, two $10 \mathrm{~g}$ (DM equivalent) samples of OL or OF-H litter were placed in $200 \mathrm{ml}$ glass jars. One sample was immediately extracted $(100 \mathrm{ml} \mathrm{KCl}$ at $1 \mathrm{M})$ and analysed for inorganic $\mathrm{N}$ $\left(\mathrm{NH}_{4}^{+}-\mathrm{N}, \mathrm{NO}_{3}^{-}-\mathrm{N}\right.$ and $\left.\mathrm{NO}_{2}^{-}-\mathrm{N}\right)$ concentrations; samples were shaken for $1 \mathrm{~h}$, filtered (Whatman No. 5 cellulose filter), and filtrates were analysed colorimetrically for $\mathrm{NH}_{4}^{+}-\mathrm{N}$ (nitroprussidesalicylate method), $\mathrm{NO}_{3}^{-}-\mathrm{N}$ (nitrosalicylic acid method) and $\mathrm{NO}_{2}^{-}-\mathrm{N}$ (sulfanilamide method) according to Bundy and Meisinger (1994). The second sample was incubated for $30 \mathrm{~d}$ at $25{ }^{\circ} \mathrm{C}$ and inorganic-N forms were analysed as above. During incubation, moisture content was verified periodically and adjusted to initial humidity (Table 1) with milli-Q water. We calculated net ammonification and net nitrification as the difference in $\left(\mathrm{NH}_{4}^{+}-\mathrm{N}\right)$ and $\left(\mathrm{NO}_{3}^{-}-\mathrm{N}+\mathrm{NO}_{2}^{-}-\mathrm{N}\right)$ concentrations, respectively, after and before the incubation.

\subsection{Enzyme activities}

Extracellular enzymes were extracted following Criquet (2002). Briefly, $10 \mathrm{~g}$ DM equivalent from each site was shaken for $1 \mathrm{~h} \mathrm{(120}$ oscillations $\left.\mathrm{min}^{-1}\right)$, extracted in $100 \mathrm{ml}$ of solution $\left(\mathrm{CaCl}_{2}{ }^{*} 2 \mathrm{H}_{2} \mathrm{O}\right.$, $0.2 \mathrm{~mol} \mathrm{l}^{-1}$ and Tween 80, 0.05\% and PVPP, $20 \mathrm{~g} \mathrm{l}^{-1}$ ), filtered with coarse nylon $(0.5 \mathrm{~mm}$ mesh) and centrifuged $(12,000 \mathrm{~g}, 20 \mathrm{~min}$, $4^{\circ} \mathrm{C}$ ). Sixteen $\mathrm{ml}$ of supernatant was filtered with Whatman filter GF/D (680 $\mu \mathrm{m}$ mesh), followed by GF/C (260 $\mu \mathrm{m}$ mesh) and

Table 1

Physicochemical properties of litter by layers, stand and fertilisation treatments. Values are mean \pm SD $(n=3)$.

\begin{tabular}{|c|c|c|c|c|c|c|}
\hline \multirow[t]{2}{*}{ Layer/properties } & \multicolumn{2}{|l|}{ Aleppo Pine } & \multirow{2}{*}{$\frac{\text { Mixed }}{\text { Unfertilised }}$} & \multirow[b]{2}{*}{ Fertilised } & \multirow{2}{*}{$\frac{\text { Holm Oak }}{\text { Unfertilised }}$} & \multirow[b]{2}{*}{ Fertilised } \\
\hline & Unfertilised & Fertilised & & & & \\
\hline \multicolumn{7}{|l|}{ OL layer } \\
\hline Organic matter (\%) & 94.9 & - & 93.5 & - & 92.8 & - \\
\hline $\mathrm{NH}_{4}-\mathrm{N}\left(\mu \mathrm{g} \mathrm{g}^{-1}\right)$ & $211 \pm 92$ & $843 \pm 540$ & $150 \pm 25$ & $411 \pm 184$ & $182 \pm 25$ & $2811 \pm 1123$ \\
\hline $\mathrm{NO}_{3}-\mathrm{N}\left(\mu \mathrm{g} \mathrm{g}^{-1}\right)$ & $0.5 \pm 0.9$ & $2.5 \pm 4.3$ & $0.2 \pm 0.9$ & $4.8 \pm 6.6$ & $1.0 \pm 0.9$ & $13.0 \pm 3.7$ \\
\hline Gravimetric water content (\%) & $38 \pm 8$ & $37 \pm 5$ & $24 \pm 4$ & $34 \pm 4$ & $27 \pm 4$ & $32 \pm 4$ \\
\hline $\mathrm{pH}$ in water & $5.7 \pm 0.3$ & $5.8 \pm 0.4$ & $5.4 \pm 0.1$ & $5.3 \pm 0.2$ & $5.3 \pm 0.2$ & $5.4 \pm 0.1$ \\
\hline \multicolumn{7}{|l|}{ OF-H layer } \\
\hline Organic matter (\%) & 71.3 & - & 78.6 & - & 73.0 & - \\
\hline $\mathrm{C}(\%)$ & $40.4 \pm 3.59$ & - & $39.3 \pm 4.24$ & - & $38.2 \pm 3.41$ & - \\
\hline $\mathrm{N}(\%)$ & $1.01 \pm 0.14$ & - & $1.15 \pm 0.29$ & - & $1.18 \pm 0.11$ & - \\
\hline $\mathrm{C} / \mathrm{N}$ & $40.5 \pm 5.1$ & - & $35.9 \pm 8.1$ & - & $32.3 \pm 3.9$ & - \\
\hline $\mathrm{NH}_{4}-\mathrm{N}\left(\mu \mathrm{g} \mathrm{g}^{-1}\right)$ & $510 \pm 241$ & $1706 \pm 593$ & $1143 \pm 479$ & $2451 \pm 1171$ & $818 \pm 527$ & $1562 \pm 783$ \\
\hline $\mathrm{NO}_{3}-\mathrm{N}\left(\mu \mathrm{g} \mathrm{g}^{-1}\right)$ & $22.2 \pm 30.7$ & $45.8 \pm 30.9$ & $45.8 \pm 18.2$ & $50.4 \pm 31.0$ & $16.6 \pm 3.2$ & $123 \pm 68$ \\
\hline Gravimetric water content (\%) & $57 \pm 6$ & $55 \pm 4$ & $61 \pm 1$ & $57 \pm 2$ & $58 \pm 5$ & $56 \pm 2$ \\
\hline $\mathrm{pH}$ in water & $6.8 \pm 0.1$ & $6.9 \pm 0.2$ & $6.6 \pm 0.3$ & $6.4 \pm 0.0$ & $6.6 \pm 0.3$ & $5.6 \pm 0.2$ \\
\hline
\end{tabular}


Table 2

Effect of the forest stand on VOC properties and phenol contents in unfertilised and fertilised litter layers.

\begin{tabular}{|c|c|c|c|c|c|c|}
\hline \multirow[b]{3}{*}{ Treatment and properties } & \multicolumn{3}{|l|}{ OL layer } & \multicolumn{3}{|l|}{ OF-H layer } \\
\hline & \multirow{2}{*}{$\begin{array}{l}\text { Aleppo pine } \\
(\mathrm{AP})\end{array}$} & \multirow{2}{*}{$\frac{\text { Mixed }}{(\mathrm{M})}$} & \multirow{2}{*}{$\frac{\text { Holm oak }}{(\mathrm{HO})}$} & \multirow{2}{*}{$\begin{array}{l}\text { Aleppo pine } \\
(\mathrm{AP})\end{array}$} & \multirow{2}{*}{$\frac{\text { Mixed }}{(\mathrm{M})}$} & \multirow{2}{*}{$\frac{\text { Holm oak }}{(\mathrm{HO})}$} \\
\hline & & & & & & \\
\hline \multicolumn{7}{|l|}{$\begin{array}{l}\text { Non-fertilised (NF) } \\
\text { VOC }\end{array}$} \\
\hline $\begin{array}{l}\text {-Richness } \\
\text {-Diversity } \\
\text {-Evenness } \\
\text {-Concentration (Sum of peak areas } \mathrm{g}^{-1} \text { ) }\end{array}$ & $\begin{array}{l}126 \pm 5 \mathrm{~b} \\
9.0 \pm 1.5 \mathrm{a} \\
0.07 \pm 0.01 \mathrm{a} \\
1.910^{6} \pm 1.010^{6} \mathrm{ab}\end{array}$ & $\begin{array}{l}136 \pm 5 b \\
5.8 \pm 1.4 \mathrm{a} \\
0.04 \pm 0.01 \mathrm{a} \\
2.510^{6} \pm 1.610^{6} \mathrm{~b}\end{array}$ & $\begin{array}{l}100 \pm 5 a \\
21.2 \pm 5.2 b \\
0.21 \pm 0.04 b \\
1.310^{5} \pm 9.810^{4} a\end{array}$ & $\begin{array}{l}102 \pm 3 \mathrm{~b} \\
16.2 \pm 3.1 \mathrm{a} \\
0.16 \pm 0.03 \mathrm{a} \\
1.810^{5} \pm 4.010^{4} \mathrm{a}\end{array}$ & $\begin{array}{l}116 \pm 3 \mathrm{c} \\
28.0 \pm 3.7 \mathrm{~b} \\
0.24 \pm 0.04 \mathrm{a} \\
2.110^{5} \pm 1.110^{5} \mathrm{a}\end{array}$ & $\begin{array}{l}90 \pm 5 \mathrm{a} \\
19.4 \pm 2.7 \mathrm{a} \\
0.21 \pm 0.04 \mathrm{a} \\
1.410^{5} \pm 8.810^{4} \mathrm{a}\end{array}$ \\
\hline $\begin{array}{l}\text { Phenols } \\
\text { Hydro-Soluble }\left(\mu \mathrm{g} \mathrm{g}^{-1}\right) \\
\text { Total }\left(\mu \mathrm{g} \mathrm{g}^{-1}\right)\end{array}$ & $\begin{array}{l}1013 \pm 53 a \\
8239 \pm 5235 a\end{array}$ & $\begin{array}{l}1001 \pm 26 a \\
6156 \pm 3811 a\end{array}$ & $\begin{array}{l}1377 \pm 151 b \\
2596 \pm 570 a\end{array}$ & $\begin{array}{l}434 \pm 47 a \\
1826 \pm 1233 a b\end{array}$ & $\begin{array}{l}665 \pm 148 b \\
4312 \pm 2043 b\end{array}$ & $\begin{array}{l}407 \pm 82 a \\
1315 \pm 257 a\end{array}$ \\
\hline \multicolumn{7}{|l|}{$\begin{array}{l}\text { Fertilised }(F) \\
\text { VOC }\end{array}$} \\
\hline $\begin{array}{l}\text {-Richness } \\
\text {-Diversity } \\
\text {-Evenness } \\
\text {-Concentration } \\
\text { (Sum of peak areas } \mathrm{g}^{-1} \text { ) }\end{array}$ & $\begin{array}{l}135 \pm 5 \mathrm{~b} \\
7.8 \pm 1.7 \mathrm{a} \\
0.06 \pm 0.01 \mathrm{a} \\
1.910^{6} \pm 1.010^{6} \mathrm{~b}\end{array}$ & $\begin{array}{l}129 \pm 8 \mathrm{~b} \\
10.3 \pm 4.0 \mathrm{a} \\
0.08 \pm 0.03 \mathrm{a} \\
9.610^{5} \pm 1.610^{5} \mathrm{ab}\end{array}$ & $\begin{array}{l}98 \pm 1 \mathrm{a} \\
22.4 \pm 0.7 \mathrm{~b} \\
0.23 \pm 0.01 \mathrm{~b} \\
1.310^{5} \pm 4.510^{4} \mathrm{a}\end{array}$ & $\begin{array}{l}104 \pm 8 \mathrm{a} \\
16.9 \pm 7.9 \mathrm{a} \\
0.16 \pm 0.06 \mathrm{a} \\
1.610^{5} \pm 2.710^{4} \mathrm{a}\end{array}$ & $\begin{array}{l}92 \pm 1 \mathrm{a} \\
15.1 \pm 4.7 \mathrm{a} \\
0.16 \pm 0.05 \mathrm{a} \\
1.710^{5} \pm 8.410^{4} \mathrm{a}\end{array}$ & $\begin{array}{l}97 \pm 8 \mathrm{a} \\
19.4 \pm 3.8 \mathrm{a} \\
0.20 \pm 0.05 \mathrm{a} \\
2.210^{5} \pm 2.310^{4} \mathrm{a}\end{array}$ \\
\hline \multicolumn{7}{|l|}{ Phenols } \\
\hline $\begin{array}{l}\text { Hydro-soluble }\left(\mu \mathrm{g} \mathrm{g}^{-1}\right) \\
\text { Total }\left(\mu \mathrm{g} \mathrm{g}^{-1}\right)\end{array}$ & $\begin{array}{l}966 \pm 73 a \\
6394 \pm 1893 a\end{array}$ & $\begin{array}{l}976 \pm 96 a \\
4541 \pm 706 a\end{array}$ & $\begin{array}{l}1142 \pm 239 a \\
3786 \pm 2584 a\end{array}$ & $\begin{array}{l}441 \pm 64 a \\
1617 \pm 724 a\end{array}$ & $\begin{array}{l}546 \pm 35 a \\
1713 \pm 855 a\end{array}$ & $\begin{array}{l}384 \pm 95 \mathrm{a} \\
1144 \pm 194 \mathrm{a}\end{array}$ \\
\hline
\end{tabular}

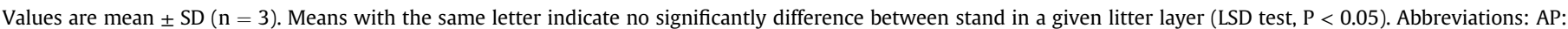
Aleppo Pine, HO: Holm oak, M: mixed stands; NF: non-fertilised, F: fertilised.

concentrated in dialysis tubing (12-14 kDa) with polyethylene glycol (PEG) for $12 \mathrm{~h}$. Enzymes were re-suspended in $10 \mathrm{ml}$ of TRIS Buffer (2 mmol $\mathrm{l}^{-1}, \mathrm{pH} 6$ ) and filtered through $20-\mu \mathrm{m}$ mesh Whatman filters).

Fluorescein diacetate hydrolase (FDAse) activity was assayed according to the procedure of Schnüner and Rosswall (1982) that we adapted for microplate analyses. Sixteen $\mu$ l of enzyme extract was incubated ( $30 \mathrm{~min}, 37^{\circ} \mathrm{C}$ in the dark) with $240 \mu \mathrm{l}$ of potassium phosphate buffer $\left(60 \mathrm{mmol} \mathrm{l}^{-1}, \mathrm{pH} 7.6\right)$ and $2 \mu \mathrm{l}$ of $\operatorname{FDA}\left(2 \mathrm{mg} \mathrm{ml}^{-1}\right)$. The fluorescein released from FDA was assessed by optical density at $490 \mathrm{~nm}$ with a spectrophotometer (Metertech ${ }^{\circledR}$ type Elisa 960). A standard curve was generated from fluorescein in solution $\left(20 \mu \mathrm{g} \mathrm{ml}^{-1}\right)$ with subsequent dilutions.

Cellulase activity was assessed following Criquet (2002). Fifty $\mu \mathrm{l}$ of enzyme extract was incubated $\left(1 \mathrm{~h}, 50^{\circ} \mathrm{C}\right.$ in the dark) with $450 \mu \mathrm{l}$ of $1 \%$ carboxymethylcellulose (CMC) solution prepared with an acetate buffer $(50 \mathrm{mM}, \mathrm{pH} 6)$. Hydrolysis of CMC releases reducing sugars which were assayed by the Somogyi-Nelson method (Somogyi, 1945; Nelson, 1944). An aliquot of $250 \mu \mathrm{l}$ was incubated with $250 \mu \mathrm{l}$ of Somogyi reagent and boiled at $100{ }^{\circ} \mathrm{C}$ for $15 \mathrm{~min}$. After cooling, $250 \mu \mathrm{l}$ of Nelson reagent and $500 \mu \mathrm{l}$ of distilled water were added. Optical density was read at $610 \mathrm{~nm}$. A standard curve was generated by replacing the enzyme extract with a glucose solution $\left(0-100 \mu \mathrm{g} \mathrm{ml}^{-1}\right)$.

Phenol oxidase activity was assessed following a modified method of Saiya-Cork et al. (2002). One hundred $\mu \mathrm{l}$ of enzyme extract was incubated $\left(25^{\circ} \mathrm{C}, 1 \mathrm{~h}\right.$ in the dark) with $100 \mu \mathrm{l}$ of $25 \mathrm{mM}$ 1-DOPA solution (L-3,4-dihydroxyphenylalanine) in an acetate buffer ( $50 \mathrm{mM}, \mathrm{pH} 6.5$ ). Optical density was read at $450 \mathrm{~nm}$. All enzymes activities were expressed as $\mu \mathrm{mol}$ of product $\mathrm{min}^{-1} \mathrm{~g}^{-1}$ litter DM.

\subsection{Data and statistical analyses}

Effects of forest stand and $\mathrm{N}$ fertilisation on microbial activities were assessed using 2 way-analysis of variance (ANOVA). The least significant difference (LSD) test was used to determine significant differences between modalities. A Student's t-test $(P<0.05)$ was also used to detect significant differences between fertilised and unfertilised treatment for a given stand type. Nitrogen fertilisation was applied to test the response of microbial functions when $\mathrm{N}$ limitation is alleviated but cannot change directly the chemistry of dead leaves. Thus we used one way (ANOVA) to compare litter biochemical properties between stands in either unfertilised or fertilised stands for each litter layer (Table 2). When necessary, data were $\log$ transformed to meet the assumptions of normality and homogeneity of variances.

We calculated the relative effects of mixed species (Non-additive effect, NAE) by comparing the observed values with the predicted values of each of the five microbial activities, based on the respective monospecific stands (pure pine and pure oak), as suggested by Wardle et al. (1997): [(observed-predicted)/ predicted $\times 100]$. If this ratio differs from zero (one-sample Student's t-tests with $95 \%$ confidence intervals), it will indicate a nonadditive effect of mixing litter on microbial activity. Significant negative and positive deviations from zero are referred to as antagonistic and synergistic effects, respectively. Statistical analyses were performed using Statistica 10.0.

We used co-inertia analyses (CIA) coupled with Monte Carlo permutation tests to assess the relationships (i.e. co-structure) between microbial and biochemical properties in litters (Thioulouse et al., 2012). CIA is a multivariate analysis technique that describes relationships between two data tables (Dray et al., 2003), and can be used even if the number of rows (i.e. sampling sites) is lower than the number of columns (i.e. variables), as it was the case of this study. Microbial properties were initially analysed by a first principal component analysis (PCA) (e.g. Fig. 4A b). Biochemical properties (Table 2 and relative abundance of all VOCs) were analysed by a second PCA (e.g Fig. 4A c). Separate PCAs find axes that maximise inertia in each data table. The CIA ordinates the forest stands for both co-structures in a single factorial map defined by two first co-inertia axes (e.g. Fig. 4A a). The canonical weights were used to determine how properties contributed to the variance of the canonical axes. To assess the significance of the CIA results, Monte Carlo permutation tests were used on the RV coefficient [0-1] to test the link between the two data tables by permuting 
simultaneously the rows of both tables. CIA was performed with the free software $\mathrm{R}$ version 2.8.1 with the package ADE4 ( $R$ Development Core Team, 2007).

\section{Results}

\subsection{Effects of stand type and $N$ fertilisation on litter secondary compounds}

In unfertilised OL litter, VOC richness was higher in pine and mixed litters than oak litter $(\mathrm{F}=40.9 ; \mathrm{P}<0.05$, Table 2$)$. The former litter types also showed the lowest VOC diversity and evenness $(\mathrm{F}=19.1$ and $\mathrm{F}=37.8$, respectively; $\mathrm{P}<0.05)$. The sum of all VOC peaks, an index of total VOC concentration, was higher $(\mathrm{F}=4.1$; $\mathrm{P}<0.05$ ) in mixed than oak litter. In pine and mixed litters (Fig. S1a and S1c, respectively), the 6 main VOCs (each accounting for $>5 \%$ of total peak area) collectively contributed for more than $70 \%$ of the total VOC concentration. These compounds belong to the sesquiand diterpene classes. The soluble phenol concentration in pine and mixed OL litters was significantly lower than in the oak litter (Table 2). Total phenol concentrations were not statistically different among litter types; however, there was a trend of decreasing concentration from pine to mixed to oak litter. The ratio of soluble to total phenols was higher in pine litter than in mixed or oak litter $(P<0.05$, not shown).

In unfertilised OF-H litter, VOC richness and diversity were the highest in the mixed stand $(F=30.4$ and $F=11.0$, respectively; $\mathrm{P}<0.05$ ), the former reaching 116 compounds, whereas VOC evenness and the sum of all VOC peaks were similar among stand types $(\mathrm{F}=3.8$ and $\mathrm{F}=0.44$, respectively; $\mathrm{P}>0.05$; Table 2$)$. The three most abundant VOCs, all monoterpenes, were common to all pine, mixed, and oak litter (also see supplementary material). Concentrations of soluble phenols were higher in the mixed stand than pine and oak litters $(\mathrm{F}=5.8 ; \mathrm{P}<0.05)$, and total phenols in the mixed litter were significantly higher than in the oak litter $(\mathrm{F}=4.1$; $\mathrm{P}<0.05$; Table 2)

Nitrogen fertilisation generally did not lead to large changes in litter biochemical properties (Table 2). However, the total VOC concentration in fertilised OL pine litter was higher than in fertilised oak litter $(\mathrm{F}=6.5 ; \mathrm{P}<0.05)$. The relative abundance of VOCs was similar to those in the unfertilised treatment. $\mathrm{N}$-fertilisation significantly decreased the VOC richness and the total phenol concentration in the mixed OF-H litter (Student's t-test, $\mathrm{P}<0.05$ ) resulting in similar richness and concentrations among the 3 stand types $(\mathrm{F}=2.2$ and 1.2 , respectively; $\mathrm{P}>0.05$; Table 2$)$.

\subsection{Effects of stand type and $\mathrm{N}$-fertilisation on microbial activities}

\subsubsection{Net ammonification and nitrification}

Stand type and $\mathrm{N}$-fertilisation both had significant effects on net ammonification in the OL litter and there was a stand type by fertilisation interaction (Table 3). Net ammonification was lower in pine and mixed litter than in oak litter (Fig. 1a). Fertilisation increased net ammonification in the pine and oak litters (Student's $t$-test, $\mathrm{P}<0.05)$. Fertilisation had a significant effect on net ammonification in OF-H litter and there was a fertilisation by stand type interaction (Table 3). In fertilised plots, net ammonification rates in all litter types were negative (Fig. 1b), and led to significantly lower rates in the mixed litter (Student's t-test, $\mathrm{P}<0.05$ ). Stand type had a significant effect on net nitrification in the OL litter with both pine and mixed litter having lower rates than oak litter (Fig. 1c). Fertilisation had a significant effect on net nitrification of the OF-H litter layer and there was a significant fertilisation by stand type interaction (Table 3). Net nitrification rates were lower in unfertilised plots of pine or mixed than oak litter (Fig. 1d), and fertilisation increased rates in the pine and mixed stands (Student's $t$-test, $\mathrm{P}<0.05$ ).

\subsubsection{Enzyme activities}

Stand type and fertilisation had a significant effect on cellulase activity in the OL litter layer, and the stand type by fertilisation interaction was significant (Table 3). This interaction revealed an increase in cellulase activities in all stand types with fertilisation, and this effect was the strongest in the mixed stand (Fig. 2a). Stand type had a significant effect on cellulase activity in the OF-H litter layer (Table 3) with highest activity in the mixed litter and lowest activity in the pine litter (Fig. 2b). Stand type and fertilisation had significant effects on FDAse activity in OL litter layer and there was a significant interaction (Table 3). Specifically, in unfertilised plots, FDAse activity was the highest in the oak stand and in fertilised plots, FDAse activity increased in the mixed and oak litters (Fig. 2c). As was the case with cellulase, stand type had a significant effect on FDAse activity in OF-H litter layer, with the highest activity in the mixed stand and the lowest in the pine (Fig. 2d). Fertilisation significantly increased phenol oxidase activity in the OL layer of the mixed stand (Fig. 2e).

\subsubsection{Non additive effect (NAE) of mixed litters}

In both unfertilised and fertilised OL litters, net-ammonification was significantly lower ( $-88 \%$ and $-76 \%$, respectively) than expected (Fig. 3A) indicating an antagonistic effect. The net nitrification was significantly lower (-69\%) than expected (Fig. 3A) in the OF-H litter whereas fertilisation resulted into an additive effect (i.e. predicted and measured not significantly different). In both OL and OF-H litters, cellulase activity was significantly higher $(+70 \%$ and $+270 \%$, respectively) than expected (Fig. 3B) only after $N$-fertilisation. In unfertilised OF-H litter, FDAse activity showed the highest and significant increase $(+640 \%)$ than expected (Fig. 3B) indicating a synergistic effect. Phenol oxidase was additive (i.e. no significant difference between predicted and measured activity, Fig. 3B).

\subsubsection{Relationships between biochemical properties and microbial activity}

Co-inertia analyses were used to test the relationships between microbial and biochemical composition. Biochemical properties (denoted by circles) and microbial properties (denoted by arrowheads) are projected in the factorial map; the shorter the arrow, the better the microbial properties are explained by the biochemical properties (Fig. 4). Our results indicate a significant co-structure between microbial and biochemical properties in the OL litter layer ( $R V=0.73, \mathrm{p}<0.01$, Monte Carlo permutation test). Specifically, oak litter had the closest microbial and biochemical costructure (shortest arrow lengths), whereas we found a decrease in co-structure similarity for mixed litter (intermediate arrow lengths), and the lowest similarity for pine litter (longest arrow lengths; Fig. 4A a). The differences between oak and the other stand types were mainly explained by the high values of FDAse activity, and net ammonification and nitrification (Fig. 4A b), whereas most of biochemical properties clearly segregated oak, on the left side of the factorial map from both pine and mixed stands being on the right side (Fig. 4A c). Fertilisation resulted in a greater separation between oak and the two other stand types (Fig. 4C a), with canonical axis 1 improving the variance explained (83.3\%). Fertilisation strongly improved the biochemical and microbial co-structure in pine (very short arrows). These effects resulted in an increase in significance of relationships ( $R V=0.83, p<0.001$, Monte Carlo permutation test).

In the OF-H litter layer, a significant co-structure was found between microbial properties and the biochemical properties 
Table 3

Results of two-way ANOVAs on the effects of forest stand (FS) and fertilisation (Fert.) on microbial activities in the OL and OF-H litter layers.

\begin{tabular}{|c|c|c|c|c|c|c|c|c|c|c|c|}
\hline \multirow[t]{2}{*}{ Factors } & \multirow[t]{2}{*}{ df } & \multicolumn{2}{|c|}{$\begin{array}{l}\text { Net } \\
\text { Ammonification }\end{array}$} & \multicolumn{2}{|c|}{ Net Nitrification } & \multicolumn{2}{|c|}{ Cellulase } & \multicolumn{2}{|c|}{ FDAse } & \multicolumn{2}{|c|}{ Phenol Oxidase } \\
\hline & & $\mathrm{F}$ & $\mathrm{P}$ & $\mathrm{F}$ & $\mathrm{P}$ & $\mathrm{F}$ & $\mathrm{P}$ & $\mathrm{F}$ & $\mathrm{P}$ & $\mathrm{F}$ & $\mathrm{P}$ \\
\hline \multicolumn{12}{|l|}{ OL layer } \\
\hline FS & 2 & 24.6 & $* * *$ & 20.5 & $* * *$ & 35.1 & $* * *$ & 28.2 & $* * *$ & 0.7 & ns \\
\hline Fert. & 1 & 22.1 & $* * *$ & 0.5 & ns & 128.0 & $* * *$ & 16.0 & $* *$ & 5.2 & $*$ \\
\hline FS x Fert. & 2 & 5.6 & $* *$ & 0.8 & ns & 21.3 & $* * *$ & 3.6 & $*$ & 4.1 & $*$ \\
\hline \multicolumn{12}{|l|}{ OF-H layer } \\
\hline FS & 2 & 0.80 & ns & 3.5 & ns & 29.6 & $* *$ & 9.0 & $* *$ & 1.4 & ns \\
\hline Fert. & 1 & 16.2 & $* * *$ & 15.1 & $* *$ & 3.0 & ns & 0.0 & ns & 0.1 & ns \\
\hline FS x Fert. & 2 & 3.2 & $*$ & 6.2 & $* *$ & 1.8 & ns & 0.7 & ns & 1.0 & ns \\
\hline Error & 12 & & & & & & & & & & \\
\hline
\end{tabular}

***, ${ }^{* *},{ }^{*}$ are $\mathrm{p}<0.001, \mathrm{p}<0.01, \mathrm{P}<0.05$, respectively.

OL

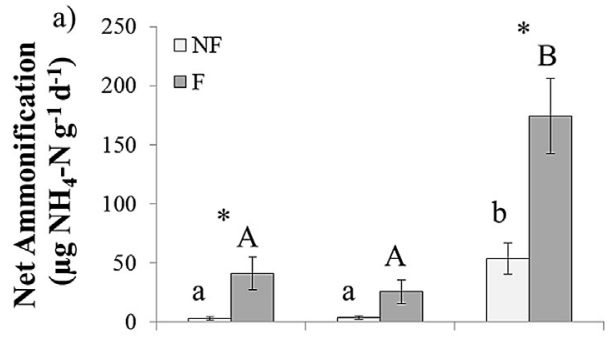

c) 1$] \square \mathrm{NF}$

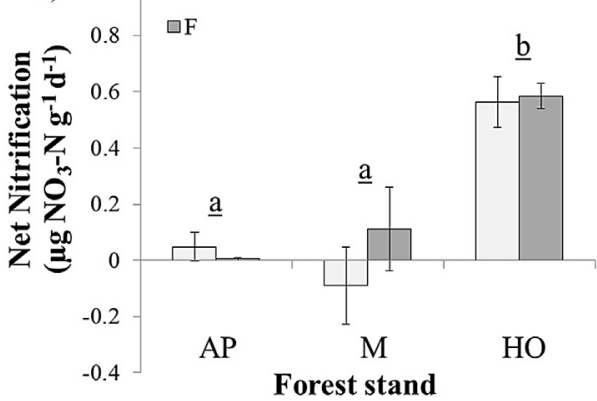

OF-H

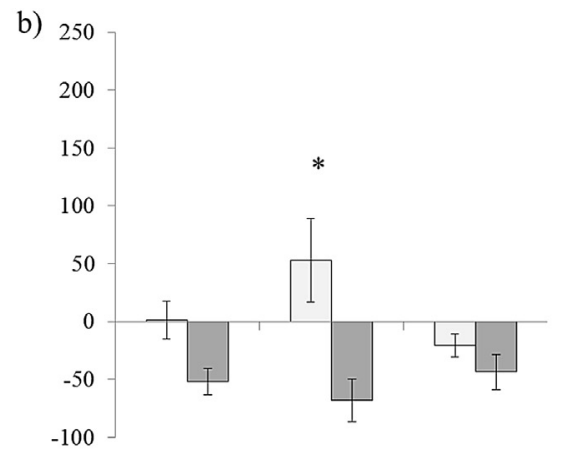

d)

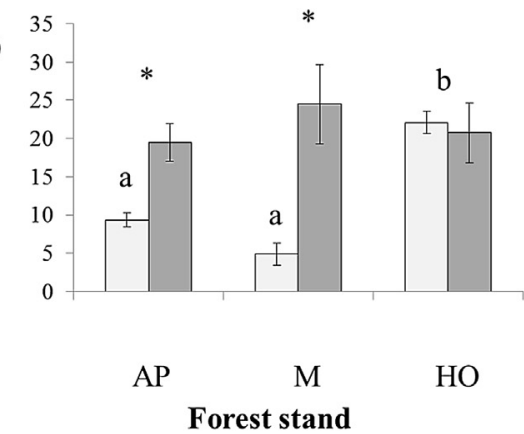

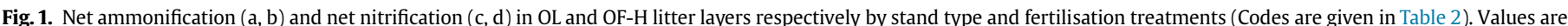

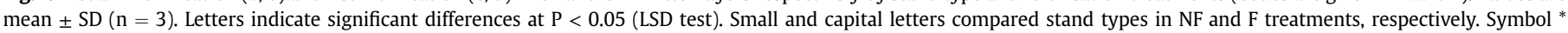

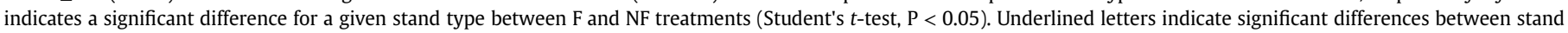
types regardless of fertilisation treatment (ANOVA main effect, $\mathrm{P}<0.05$ ).

$(\mathrm{RV}=0.73, \mathrm{p}<0.01$, Monte Carlo permutation test). The factorial map (Fig. 4B a) indicated a greater similarity between biochemical and microbial properties in oak litter (shorter arrows) than in the two other stand types, although differences were less pronounced than in OL litter layer. The mixed stand in the positive part of the factorial map along CA1 (61.8\% of the variance) differentiated from both monospecific stands, being in the negative part of the factorial map. Most of the microbial and biochemical properties converged toward the mixed stand co-structure, with the exception of net nitrification, which was strongly correlated with oak litter properties, and VOC intensity, which was correlated with pine litter properties (Fig. 4C b, and Fig. 4C c). Fertilisation resulted in a loss of co-structure significance between microbial and biochemical properties ( $\mathrm{RV}=0.65, \mathrm{p}>0.05$, Monte Carlo permutation test) (Fig. 4D).

\section{Discussion}

\subsection{Biochemical properties of pure pine and oak litters and mixing effect}

We expected mixing pine and oak litter types would result in a diluting effect of both VOCs and phenol concentrations, but we discovered that Aleppo pine dominates the composition and content of secondary compounds in OL mixed pine/oak litter. OL pine litter contains more types of VOCs (i.e. higher richness) than oak litter as expected but total VOC concentrations were not statistically different (Table 2). The latter result is surprising since Aleppo pine is a terpene storing species whereas Holm oak is a terpene non-storing species (Llusià and Peñuelas, 1999) but known as a high phenolic leaf producer (Sheffer et al., 2015). However, total phenols, 
OL
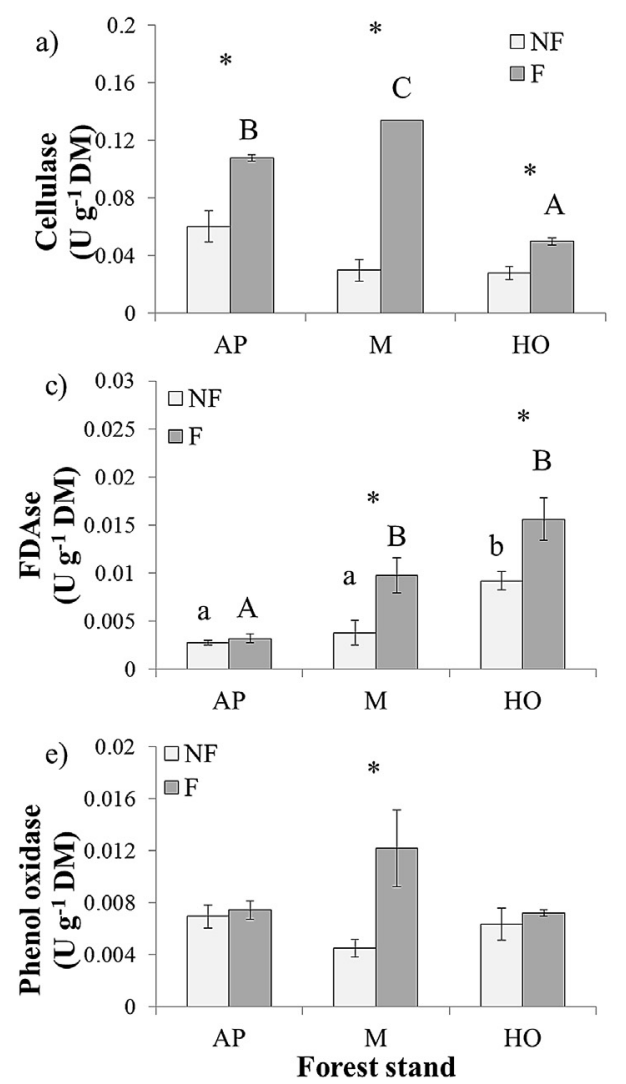

OF-H

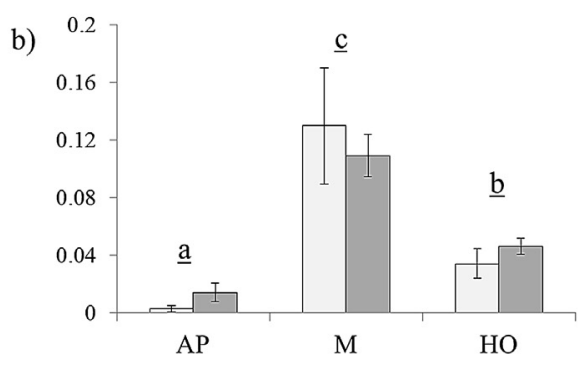

d) $0.03+\quad \underline{b}$

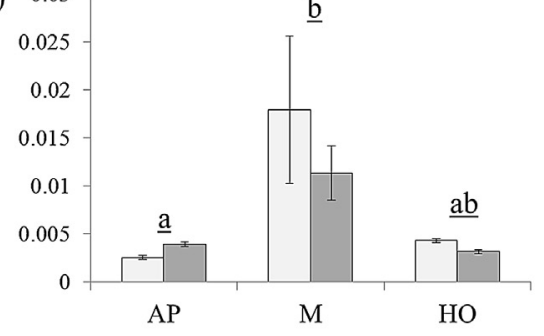

f)

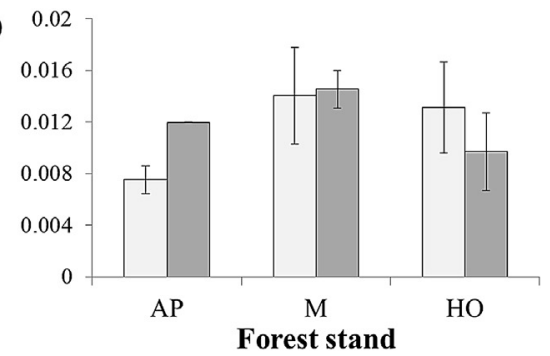

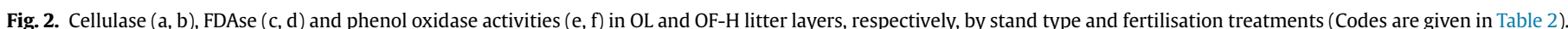

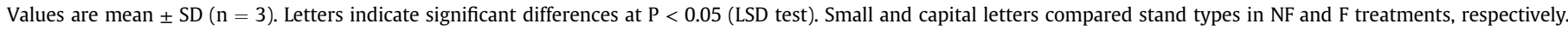

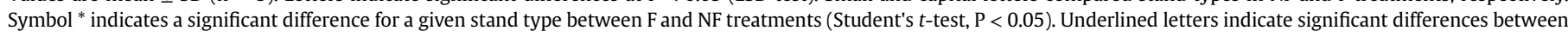
stand types regardless fertilisation treatment (ANOVA main effect, $\mathrm{P}<0.05$ ).

which included high molecular weight and condensed tannins that are potentially toxic to microbes (Fierer et al., 2001), were also found in higher concentrations in pine litter. In a meta-analysis, Dob et al. (2005) concluded that fresh needles of Aleppo pine contain 118 different VOCs, which is very similar to the number of VOCs that we extracted from pine litter (126 \pm 5 ; Table 2). Compared to Holm oak, Aleppo pine produces larger compounds such as sesqui- and diterpenes, the most abundant being $\beta$-caryophyllene (Dob et al., 2005; Ormeño et al., 2008; Chomel et al., 2014) which accounted in the current study for $24 \%$ and $39 \%$ of total VOC concentrations, in pine and mixed litters, respectively (Fig. S1a, c). Others have found that this sesquiterpene accounts for more than $40 \%$ of the total VOC intensity in live needles and OL litter of Aleppo Pine (Dob et al., 2005; Ormeño et al., 2008; Chomel et al., 2014). It is not clear why we found lower concentrations of this compound in pure pine litter, or why concentrations in mixed litter were not diluted (i.e. lower) compared to pure pine litter. It is possible that microbes living in the pure pine litter had a great affinity for native litter (Austin et al., 2014) and therefore preferentially decomposed this compound (Chomel et al., 2014). In contrast, microbial communities in the mixed litter do not seem to have this selectivity for or ability to decompose the $\beta$-caryophyllene, which only disappeared in OF-H litter (Fig. S1). In pine and mixed litter, the VOC diversity and evenness increased from OL to OF-H litter, the most spectacular being for mixed litter exceeding the ones in pure oak litter (Table 2). The increase in VOC evenness in pure pine and mixed OF-H litter may be the result of microbial decomposition of the most abundant compounds (Chomel et al., 2014) but some of the VOCs may also be products of microbial or chemical reactions that can take place during decomposition (Spinelli et al., 2011). Moreover, the most persistent VOCs in the three forest litter types were monoterpenes (Fig. S1 b,d,f). These compounds, already highly abundant in OL oak litter (Fig. S1e), could have a higher residence time than higher molecular weight compounds such as sesquiterpenes (Chomel et al., 2014). This is consistent with findings showing that monoterpenes can decrease both microbial biomass (Smolander et al., 2006) and $\mathrm{N}$-cycling activities (White, 1994). Overall these results, suggest pine produces the most recalcitrant (i.e. unfavourable and persistent) litter quality.

\subsection{Mixed litters facilitate microbial activity}

Recent research on Mediterranean ecosystems has focused on how plant species mixtures and their relative composition can improve nutrient availability (e.g. De Marco et al., 2011) through litter mass loss (Sheffer et al., 2015), and could explain transitions in forest secondary succession (Fierer et al., 2001) from pure pine stand to more diversified forests.

Pine needles are recognised as biochemically and physically recalcitrant to decomposition to soil microbes due to its high concentrations of secondary compounds such as phenols and terpenes (Berg et al., 1980; Kuiters, 1990) and affect nutrient availability. This was confirmed by co-inertia analysis revealing the 

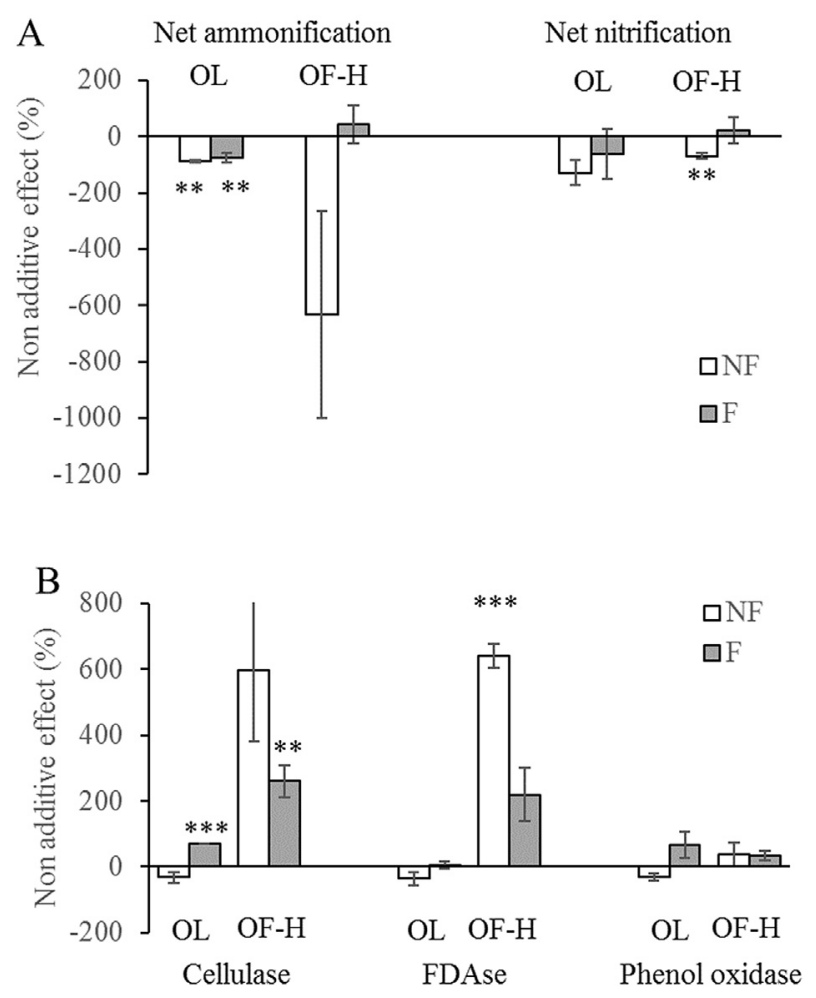

Fig. 3. Non additive effect (NAE, \%) on Net ammonification and Net nitrification (A), cellulase, FDAse and phenol oxidase (B) in OL and OF-H litter layers, by fertilisation treatment. Values are mean \pm SD $(n=3)$. NAE significantly different from zero, according to one-sample Student's t-test are indicated by ${ }^{* *}$ or ${ }^{* * *}$ for $\mathrm{p}<0.01$ and $\mathrm{p}<0.001$, respectively.

closest and significant biochemical-microbial co-structure in pure pine litter after $\mathrm{N}$ fertilisation (Fig. $4 \mathrm{C}$ a). This result demonstrated that $\mathrm{N}$ is a major limiting factor connecting litter biochemistry and microbial activities in pure pine litter. We also found that pine litter shaped the biochemical composition in OL (i.e. intact) mixed litter and its related microbial activities (Fig. 4A). This contradicts with our hypothesis that pine litter when mixed with oak litter should dilute its biochemical compounds (Table 2) by a complementarity effect and in turn, would increase microbial activities (Figs. 1 and 2). For example, FDA hydrolysis, which involves a pool of many hydrolases (Sánchez-Monedero et al., 2008), and net ammonification were as low in mixed litter as they were in pure pine litter. This indicates that the secondary compounds from pine probably inhibited microbial activities associated with oak litter (i.e. antagonistic effect, Fig. 3A). In this case, our results also indicated that $\mathrm{N}$ availability is not involved in the regulation of these effects. Indeed, $\mathrm{N}$ fertilisation in OL litter did not overcome these antagonistic effects (Fig. 3A and B), rejecting our second hypothesis on the role of $\mathrm{N}$ limitation. On the contrary, the latter antagonistic effects disappeared in OF-H litter (i.e. advanced litter decomposition), even turning into a synergistic effect for FDAse activity (Fig. 3B). Whereas this litter layer presented diluted concentrations of VOCs and a high VOCs diversity (as we hypothesised), the poor $\mathrm{N}$ availability in mixed litter along with high microbial activities suggest other factors could explain this increase in the total hydrolase activities. For example, a microbial community specialisation involved into nutrient recovery (see discussion below) that would depend on a microbial C allocation patterns (i.e. life history strategy, but see Schimel and Schaeffer, 2012). The effect of mixed litter on the cellulase activity was clearly synergistic (Fig. 3B) but it was also constrained by $\mathrm{N}$ availability (Sinsabaugh et al., 2002) and could be explained by other biochemical compounds. Indeed, concentrations of both hydro-soluble and total phenols in this OF-H litter layer were the highest in mixed litter. Phenols can indirectly limit $\mathrm{N}$ availability by forming recalcitrant polyphenol-organic-N complexes (Wurzburger and Hendrick, 2007). This could give a certain advantage to some fungi that are able to use this form of sequestered organic-N (Wurzburger and Hendrick, 2009), as shown by the better growth of fungi than bacteria (Fig. S3d). Despite a lower N availability in mixed litter, microbial enzyme activities were the greatest potentially indicating a specialisation of the microbial communities in favour of fungi, the latter being less constrained by $\mathrm{N}$ availability than bacteria. Current results from phenol oxidases activity support this hypothesis. Indeed, phenol oxidase usually produced by fungi did not decrease after $\mathrm{N}$ fertilisation (Fig. 2) as expected (Keeler et al., 2009) but rather, strongly increased, suggesting a strong potential for mixed litter decomposition (SaiyaCork et al., 2002). Importantly, pine litter slowed down N cycling through its negative effects on nitrification. Because heterotrophs usually use less $\mathrm{NH}_{4}$ than $\mathrm{NO}_{3}$ to avoid competition with nitrifiers (Burger and Jackson, 2003), pine litter, by inhibiting nitrification and thus lowering $\mathrm{NO}_{3}$ availability, could have a large effect on plant productivity (Hobbie, 1992). The inherently high rate of nitrification in pure oak litter, and the lack of stimulation by fertilisation illustrate that pine litter inhibits this process both in pure (e.g. White, 1994) and in mixed litter. It is not clear how mixed litter, which we found improving enzyme activities but not nitrification rates, could be responsible for the greater plant productivity previously observed in these mixed stands (Vilà et al., 2007). Fertilisation confirmed that nitrification rates were mostly limited in mixed litter, this litter type also having the highest phenol concentrations. Together, this suggests that microbial communities of the mixed litter had the greatest enzymes activities for $\mathrm{N}$ recovery.

Contrary to our initial hypothesis, a complementarity effect resulted from both the mixing of litter compounds, and changes in litter chemistry driven by microbial decomposition (Wickings et al., 2012). This appeared to be primarily the result of direct consumption (assimilation or catabolism) of the most abundant compounds (Sjöberg and Persson, 1998; Chomel et al., 2014). Enzymes activities in OL mixed litter were all constrained by $\mathrm{N}$ availability suggesting strong $\mathrm{N}$ demand by microbes for enzyme synthesis (Caldwell, 2005). In contrast, the frequent and beneficial effects of mixed litter on microbial activities in fragmented and oxidized OF$\mathrm{H}$ litter layer indicate that a complementarity effect can be due to either a decrease in inhibitory effect of secondary compounds (e.g. enzyme activities, net ammonification, fungal growth) or an increase in resource diversification (e.g. bacterial catabolic diversity) and that these effects were not limited by $\mathrm{N}$ availability despite an apparent nitrification limitation, suggesting microbial specialisation and efficiency for $\mathrm{N}$ acquisition.

Most studies of litter mixtures have included at least one litter species of high quality. Litters of Aleppo pine and Holm oak are both recalcitrant and relatively unfavourable to soil microbes (i.e. low quality litter) but are suspected to stimulate microbial activities when mixed by a complementarity effect. Pine clearly shaped the biochemical composition in OL mixed litter, dominated by high molecular weight compounds (total phenols, sesqui and di terpenes). On the contrary, oak litter contained small compounds such as mono terpenes and hydro-soluble phenols. Pine litter clearly affected microbial activities (i.e. antagonistic effect) in unfertilised OL mixed litter. We demonstrated by co-inertia analysis that this antagonistic effect was related to $\mathrm{N}$-availability. In $\mathrm{OF}-\mathrm{H}$ mixed litter, we found the highest VOC richness and evenness, along with the best enzyme activities (i.e. synergistic effect) whereas $\mathrm{N}$ availability was not constraining microbial activities. However, an apparent nitrification limitation suggests microbial specialisation 
OL
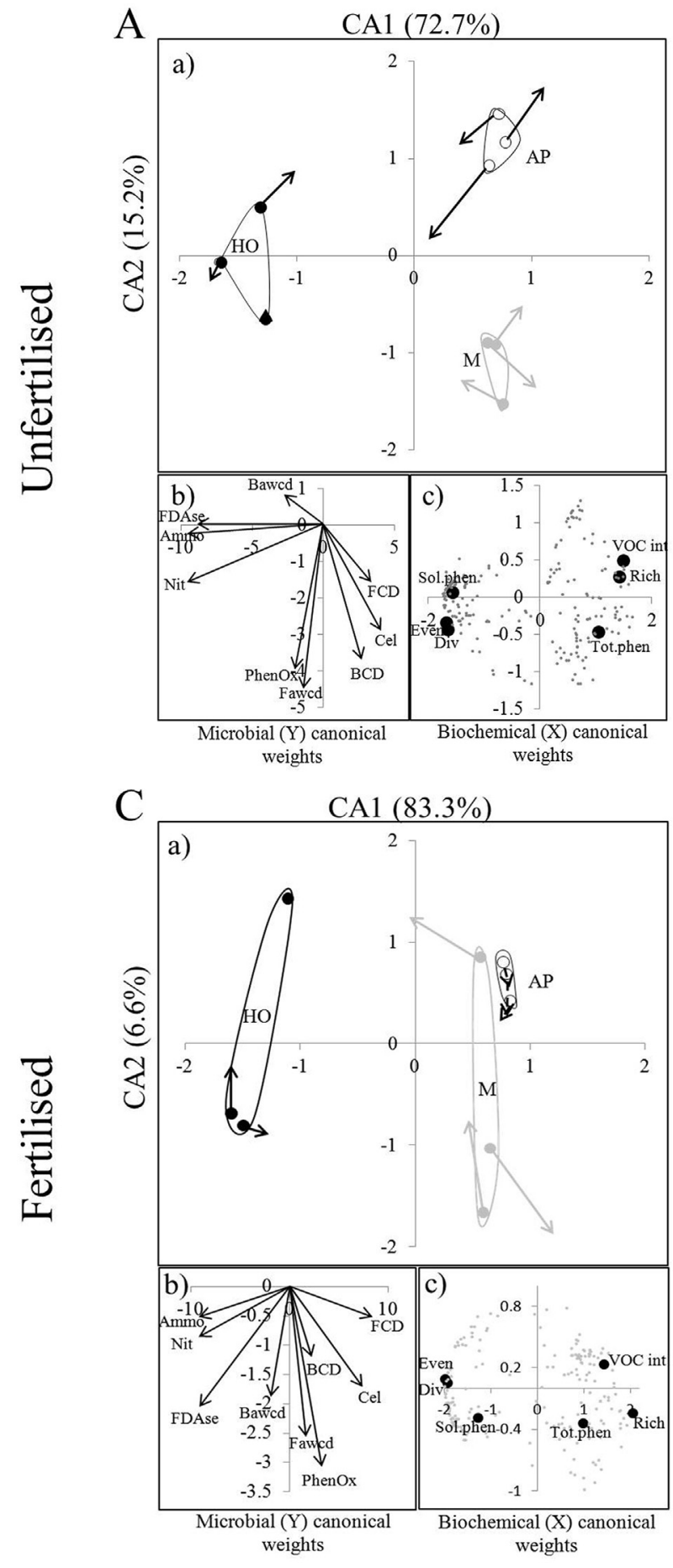

\section{$\mathrm{OF}-\mathrm{H}$}
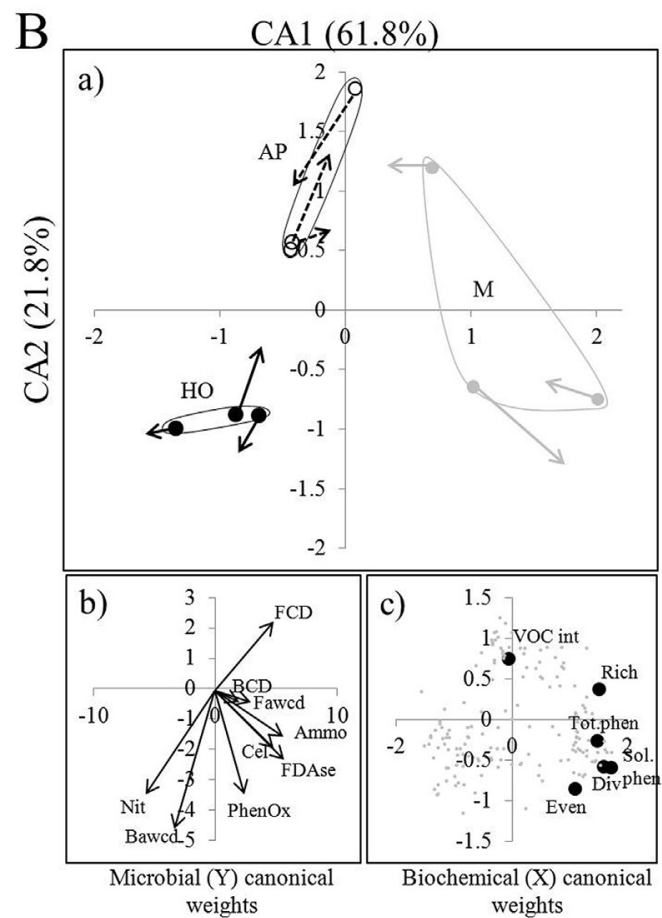

$\mathrm{D}$
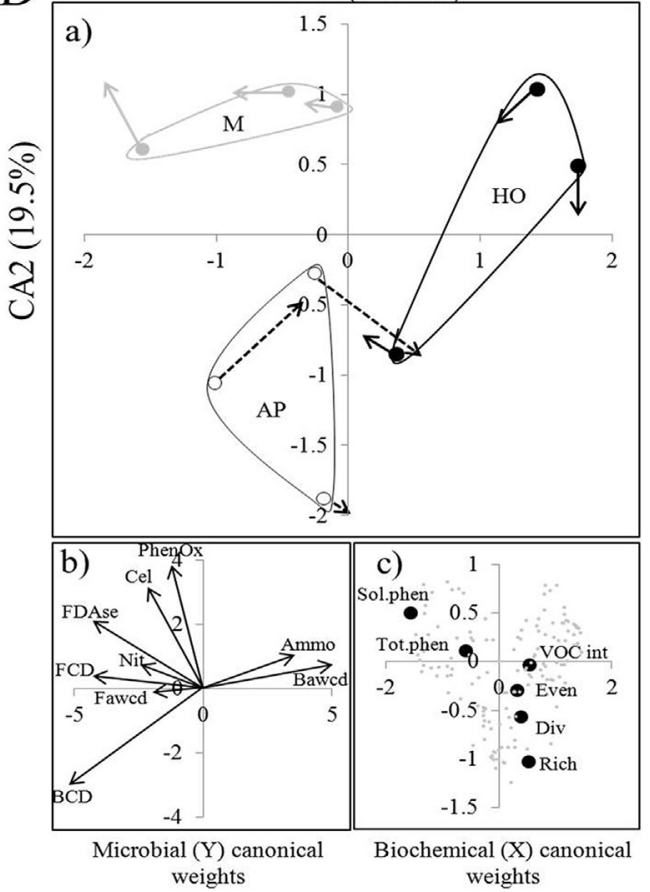

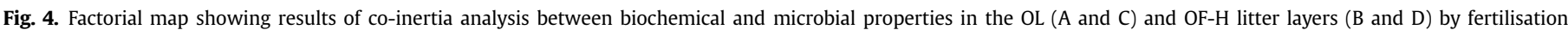

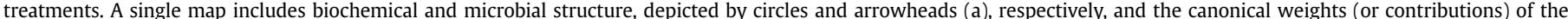

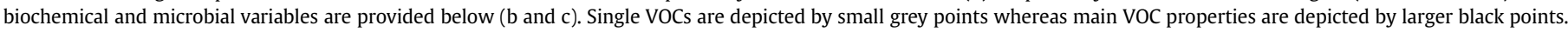

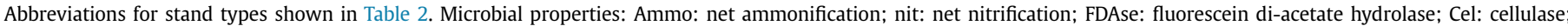

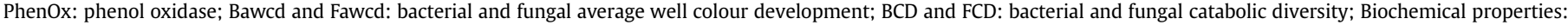
VOC int: VOC intensity; Rich: VOC richness, Tot. phen: total phenol content; Sol. phen: soluble phenol content; Even: VOC evenness; Div: VOC diversity.

and efficiency for $\mathrm{N}$ recovery. Our study is consistent with the idea that the positive relationship between plant litter diversity and microbial activities depends on $\mathrm{N}$ availability, specifically in
Mediterranean ecosystems. Future tests that include the litter of other dominant species of these Mediterranean forests such as Downy oak will be useful. 


\section{Acknowledgements}

Authors are grateful to F. Ruaudel for her technical assistance. This research did not receive any specific grant from funding agencies in the public, commercial, or not-for-profit sectors, with the exception of US NSF grant DEB- 1256180 which provided partial support of RG and TAD for preparation of this manuscript.

\section{References}

Aponte, C., García, L.V., Marañón, T., 2012. Tree species effect on litter decomposition and nutrient release in Mediterranean oak forests changes over time. Ecosystems 15, 1204-1218.

Austin, A.T., Vivanco, L., González-Arzac, A., Pérez, L.I., 2014. There's no place like home? An exploration of the mechanisms behind plant litter-decomposer affinity in terrestrial ecosystems. New Phytologist 204, 307-314.

Barlecher, F., Graça, M.A.S., 2005. Total phenolics, In Graça, M.A.S., Barlecher, F., Gnesser, M.O. (eds), Methods to Study Litter Decomposition: a Practical Guide. Springer netherlands. p 97-100.

Berg, B., Hannus, K., Popoff, T., Theander, O., 1980. Chemical components of Scots pine needles and needle litter and inhibition of fungal species by extractives, pp. 391-400. In: Structure and Function of Northern Coniferous Forests. An Ecosystem Study Ecological Bulletins, vol. 32, pp. 391-400.

Bonanomi, G., Incerti, G., Antignani, V., Capodilupo, M., Mazzoleni, S., 2010. Decomposition and nutrient dynamics in mixed litter of Mediterranean species Plant and Soil 331, 481-496.

Bonanomi, G., Incerti, G., Capodilupo, M., Mazzoleni, S., 2014. Nitrogen transfer in litter mixture enhances decomposition rate, temperature sensitivity, and C quality changes. Plant and Soil 381, 307-321.

Brossa, R., Casals, I., Pintó-Marijuan, M., Fleck, I., 2009. Leaf flavonoid content in Quercus ilex L. resprouts and its seasonal variation. Trees 23, 401-408.

Bundy, L.G., Meisinger, J.J., 1994. Nitrogen availability indices. In: Weaver, R.W. Angle, J.S., Bottomley, P.S. (Eds.), Methods of Soil Analysis, Part 2 - Microbiological and Biochemical Properties. SSSA, Wisconsin, USA, pp. 951-954. Book series: 5.

Burger, M., Jackson, L.E., 2003. Microbial immobilization of ammonium and nitrate in relation to ammonification and nitrification rates in organic and conventional cropping. Soil Biology and Biochemistry 35, 29-36.

Caldwell, B.A., 2005. Enzyme activities as a component of soil biodiversity: a review. Pedobiologia 49, 637-644.

Castells, E., Penuelas, J., Valentine, D.W., 2004. Are phenolic compounds released from the Mediterranean shrub Cistus albidus responsible for changes in N cycling in siliceous and calcareous soils? New Phytologist 162, 187-195.

Chapman, K., Whittaker, J.B., Heal, O.W., 1988. Metabolic and faunal activity in litters of tree mixtures compared with pure stands. Agriculture, Ecosystems and Environment 24, 33-40.

Chapman, S.K., Koch, G.W., 2007. What type of diversity yields synergy during mixed litter decomposition in a natural forest ecosystem? Plant and Soil 299, $153-162$.

Chapman, S.K., Newman, G.S., Hart, S.C., Schweitzer, J.A., Koch, G.W., 2013. Leaf litter mixtures alter microbial community development: mechanisms for nonadditive effects in litter decomposition. PlosOne 8, e62671.

Chomel, M., Fernandez, C., Bousquet-Mélou, A., Gers, C., Monnier, Y., Santonja, M. Gauquelin, T., Gros, R., Lecareux, C., Baldy, V., 2014. Secondary metabolites of Pinus halepensis alter decomposer organisms and litter decomposition during afforestation of abandoned agricultural zones. Journal of Ecology 102, 411-424.

Chomel, M., Guitonny-Larchêque, M., Desrochers, A., Baldy, V., 2015. Home field advantage of litter decomposition in pure and mixed plantations under borea climate. Ecosystems 18, 1014-1028.

Criquet, S., 2002. Measurement and characterization of cellulase activity in sclerophyllous forest litter. Journal of Microbiological Methods 50, 165-173.

De Marco, A., Meola, A., Maisto, G., Giordano, M., Virzo De Santo, A., 2011. Nonadditive effects of litter mixtures on decomposition of leaf litters in a Mediterranean maquis. Plant and Soil 344, 305-317.

De Oliveira, T., Hättenschwiler, S., Handa, I.T., 2010. Snail and millipede complementarity in decomposing Mediterranean forest leaf litter mixtures. Functional Ecology 24, 937-946.

Dob, T., Berramdane, T., Chelgoum, C., 2005. Chemical composition of essential oil of Pinus halepensis Miller growing in Algeria. Comptes Rendus Chimie 8 1939-1945.

Dray, S., Chessel, D., Thioulouse, J., 2003. Co-inertia analysis and the linking of ecological data tables. Ecology 84, 3078-3089.

Fernandez, C., Santonja, M., Gros, R., Monnier, Y., Chomel, M., Baldy, V., BousquetMélou, A., 2013. Allelochemicals of Pinus halepensis as drivers of biodiversity in Mediterranean open mosaic habitats during the colonization stage of secondary succession. Journal of Chemical Ecology 39, 298-311.

Fierer, N., Schimel, J.P. Cates, R.G., Zou, J., 2001. Influence of balsam poplar tannin fractions on carbon and nitrogen dynamics in Alaskan taiga floodplain soils. Soil Biology and Biochemistry 33, 1827-1839.

Fioretto, A., Musacchio, A., Andolfi, G., De Santo, A.V., 1998. Decomposition dynamics of litters of various pine species in a Corsican pine forest. Soil Biology and Biochemistry 30, 721-727.

Folin, O., Denis, W., 1915. A colorimetric method for the determination of phenols (and phenol derivatives) in urine. Journal of Biological Chemistry $22,305-308$.

Gartner, T.B., Cardon, Z.G., 2004. Decomposition dynamics in mixed species leaf litter. Oikos 104, 230-246.

Guénon, R., Vennetier, M., Pailler, A., Dupuy, N., Roussos, S., Gros, R., 2013. Trends in recovery of Mediterranean soil chemical properties and microbial activities after infrequent and frequent wildfires. Land Degradation and Development 24, 115-128.

Hättenschwiler, S., Vitousek, P., 2000. The role of polyphenols in terrestrial ecosystem nutrient cycling. Trends in Ecology and Evolution 15, 238-243.

Hobbie, S.E., 1992. Effects of plant species on nutrient cycling. Trends in Ecology and Evolution 7, 336-339.

Keeler, B.L., Hobbie, S.E., Kellogg, L.E., 2009. Effects of long-term nitrogen addition on microbial enzyme activity in eight forested and grassland sites: implications for litter and soil organic matter decomposition. Ecosystems 12, 1-15.

Kuiters, A.T., 1990. Role of phenolic substances from decomposing forest litter in plant-soil interactions. Acta Botanica Neerlandica 39, 329-348.

Lecerf, A., Marie, G., Kominoski, G., LeRoy, C.J., Bernadet, C., Swan, C.M., 2011. Incubation time, functional litter diversity, and habitat characteristics predict litter-mixing effects on decomposition. Ecology 92, 160-169.

Leff, J.W., Fierer, N., 2008. Volatile organic compound (VOC) emissions from soil and litter samples. Soil Biology and Biochemistry 40, 1629-1636.

Llusià, J., Peñuelas, J., 1999. Pinus halepensis and Quercus ilex terpene emission as affected by temperature and humidity. Biologia Plantarum 42, 317-320.

Maisto, G., De Marco, A., Meola, A., Sessa, L., Virzo De Santo, A., 2011. Nutrient dynamics in litter mixtures of four Mediterranean maquis species decomposing in situ. Soil Biology and Biochemistry 43, 520-530.

Nelson, M., 1944. Photometric adaptation of Somogyi method for determination of glucose. Journal of Biological Chemistry 153, 375-380.

Ormeño, E., Baldy, V., Ballini, C., Fernandez, C., 2008. Production and diversity of volatile terpenes from plants on calcareous and siliceous soils: effect of soil nutrients. Journal of Chemical Ecology 34, 1219-1229.

Paquette, A., Messier, C., 2011. The effect of biodiversity on tree productivity: from temperate to boreal forests. Global Ecology and Biogeography 20, 170-180.

Parrotta, J.A., 1999. Productivity, nutrient cycling, and succession in single- and mixed-species plantations of Casuarina equisetifolia, Eucalyptus robusta, and Leucaena leucocephala in Puerto Rico. Forest Ecology and Management 124, 45-77.

Pausas, J.G., Blade, C., Valdecantos, A., Seva, J.P., Fuentes, D., Alloza, J.A., Vilagrosa, A., Bautista, S., Cortina, J., Vallejo, R., 2004. Pines and oaks in the restoration of Mediterranean landscapes in Spain: new perspectives for an old practice - a review. Plant Ecology 171, 209-220.

R Development Core Team, 2007. R: A language and environment for statistical computing. R Foundation for Statistical Computing, Vienna, Austria.

Royer-Tardif, S., Bradley, R.L., Parsons, W.F.J., 2010. Evidence that plant diversity and site productivity confer stability to forest floor microbial biomass. Soil Biology and Biochemistry 42, 813-821.

Saiya-Cork, K., Sinsabaugh, R., Zak, D., 2002. The effects of long term nitrogen deposition on extracellular enzyme activity in an Acer saccharum forest soil. Soil Biology and Biochemistry 34, 1309-1315.

Sánchez-Monedero, M.A., Mondini, C., Cayuela, M.L., Roig, A., Contin, M., De Nobili, M., 2008. Fluorescein diacetate hydrolysis, respiration and microbial biomass in freshly amended soils. Biology and Fertility of Soils 44, 855-890.

Santonja, M., Baldy, V., Fernandez, C., Balesdent, J., Gauquelin, T., 2015. Potential shift in plant communities with climate change: outcome on litter decomposition and nutrient release in a Mediterranean oak forest. Ecosystems 18, $1253-1268$

Sheffer, E., 2012. A review of the development of Mediterranean pine-oak ecosystems after land abandonment and afforestation: are they novel ecosystems? Annals of Forest Science 69, 429-443.

Sheffer, E., Canham, C.D., Kigel, J., Perevolotsky, A., 2015. Countervailing effects on pine and oak leaf litter decomposition in human-altered Mediterranean ecosystems. Oecologia 177, 1039-1051.

Schimel, J.P., Schaeffer, S.M., 2012. Microbial control over carbon cycling in soil. Frontier in Microbiology 3, 1-11.

Schnüner, J., Rosswall, T., 1982. Fluoresceine diacetate hydrolysis as a measure of total microbial activity in soil and litter. Applied and Environmental Microbiology 43, 1256-1261.

Sinsabaugh, R.L., Carreiro, M.M., Repert, D.A., 2002. Allocation of extracellular enzymatic activity in relation to litter composition, $\mathrm{N}$ deposition, and mass loss. Biogeochemistry 60, 1-24.

Sjöberg, R.M., Persson, T., 1998. Turnover of carbon and nitrogen in coniferous forest soils of different $\mathrm{N}$-status and under different 15NH4-N application rate. Environmental Pollution 102, 385-393.

Smolander, A., Ketola, R.A., Kotiaho, T., Kanerva, S., Suominen, K., Kitunen, V., 2006. Volatile monoterpenes in soil atmosphere under birch and conifers: effects on soil N transformations. Soil Biology and Biochemistry 38, 3436-3442.

Somogyi, M., 1945. A new reagent for determination of sugars. Journal of Biological 
Chemistry 160, 61.

Song, F., Fan, X., Song, R., 2010. Review of mixed forest litter decomposition researches. Acta Ecologica Sinica 30, 221-225.

Spinelli, F., Cellini, A., Marchetti, L., Nagesh, K.M., Piovene, C., 2011. In: Arun Shanker (Ed.), Emission and Function of Volatile Organic Compounds in Response to Abiotic Stress, Abiotic Stress in Plants - Mechanisms and Adaptations. InTech, ISBN 978-953-307-394-1.

Thioulouse, J., Prin, Y., Duponnois, R., 2012. Multivariate analyses in soil microbial ecology: a new paradigm. Environmental and Ecological Statitics 19, 499-520.

Vilà, M., Vayreda, J., Gracia, C., Ibáñez, J.J., 2003. Does tree diversity increase wood production in pine forests? Oecologia 135, 299-303.

Vilà, M., Vayreda, J., Comas, L., Ibáñez, J.J., Mata, T., Obón, B., 2007. Species richness and wood production: a positive association in Mediterranean forests. Ecology Letters 10, 241-250.

Vos, V.C.A., van Ruijven, J., Berg, M.P., Peeters, E.T.H.M., Berendse, F., 2013. Leaf litter quality drives litter mixing effects through complementary resource use among detritivores. Oecologia 173, 269-280.

Wardle, D.A., Bonner, K.I., Nicholson, K.S., 1997. Biodiversity and plant litter: experimental evidence which does not support the view that enhanced species richness improves ecosystem function. Oikos 79, 247-258.
Wardle, D.A., Yeates, G.W., Barker, G.M., Bonner, K.I., 2006. The influence of plant litter diversity on decomposer abundance and diversity. Soil Biology and Biochemistry 38, 1052-1062.

Wickings, K., Grandy, S.A., Reed, S.C., Cleveland, C.C., 2012. The origin of litte chemical complexity during decomposition. Ecology Letters 15, 1180-1188.

White, C.S., 1988. Nitrification inhibition by monoterpenoids - theoritical mode of action based on molecular structure. Ecology 69, 1631-1633.

White, C.S., 1994. Monoterpenes - their Effects on ecosystem nutrient cycling. Journal of Chemical Ecology 20, 1381-1406.

Wurzburger, N., Hendrick, R.L., 2007. Rhododendron thickets alter N cycling and soil extracellular enzyme activities in southern Appalachian hardwood forests Pedobiologia 50, 563-576.

Wurzburger, N., Hendrick, R.L., 2009. Plant litter chemistry and mycorrhizal roots promote a nitrogen feedback in a temperate forest. Journal of Ecology 97 528-536.

Yuste, J.C., Barba, J., Fernandez-Gonzalez, A.J., Fernandez-Lopez, M., Mattana, S. Martinez-Vilalta, J., Nolis, P., Lloret, F., 2012. Changes in soil bacterial community triggered by drought-induced gap succession preceded changes in soil C stocks and quality. Ecology and Evolution 2, 3016-3031. 